\title{
The effects of CEP-37440, an inhibitor of focal adhesion kinase, in vitro and in vivo on inflammatory breast cancer cells
}

\author{
Israa Salem', Manal Alsalahi', Inna Chervoneva², Lucy D. Aburto', Sankar Addya ${ }^{3}$, Gregory R. Ott ${ }^{4}$,
} Bruce A. Ruggeri ${ }^{4,6}$, Massimo Cristofanilli ${ }^{1,5}$ and Sandra V. Fernandez ${ }^{1 *}$

\begin{abstract}
Background: Inflammatory breast cancer (IBC) is an aggressive type of advanced breast cancer with a poor prognosis. We recently found that focal adhesion kinase 1 (FAK1) is upregulated and phosphorylated (active) in IBC. In this study, we investigated the effect of CEP-37440, a dual inhibitor of FAK1 and anaplastic lymphoma kinase (ALK), using human IBC cell lines and preclinical models of IBC.

Methods: Cell proliferation assays were performed in the presence of several concentrations of CEP-37440 using IBC and triple-negative breast cancer non-IBC cell lines. In vitro, we studied the expression of total FAK1, phospho-FAK1 (Tyr 397), total ALK and phospho-ALK (Tyr 1604). In vivo, we tested CEP-37440 using FC-IBC02, SUM149, and SUM190 IBC xenograft mouse models.

Results: CEP-37440 at low concentration decreased the proliferation of the IBC cell lines FC-IBC02, SUM190, and KPL4, while not affecting the proliferation of normal breast epithelial cells. At higher concentration, CEP-37440 was also able to inhibit the proliferation of the IBC cell line MDA-IBCO3 and the triple-negative non-IBC cell lines MDA-MB-231 and MDA-MB-468; the IBC cell line SUM149 showed a slight response to the drug. CEP-37440 decreased the cell proliferation of FC-IBC02, SUM190, and KPL4 by blocking the autophosphorylation kinase activity of FAK1 (Tyr 397). None of the cells evaluated expressed ALK. In vivo, after 7 weeks of CEP-37440 treatment, the SUM190, FC-IBC02, and SUM149 breast tumor xenografts were smaller in mice treated with $55 \mathrm{mg} / \mathrm{kg}$ bid CEP-37440 compared to the controls; the tumor growth inhibition (TGI) was $79.7 \%, 33 \%$, and $23 \%$, respectively. None of the FC-IBC02 breast xenografts mice treated with CEP-37440 developed brain metastasis while $20 \%$ of the mice in the control group developed brain metastasis. Expression array analyses in FC-IBC02 cells showed that CEP-37440 affects the expression of genes related to apoptosis, interferon signaling, and cytokines.
\end{abstract}

Conclusions: CEP-37440 is effective against some IBC cells that express phospho-FAK1 (Tyr 397), and its antiproliferative activity is related to its ability to decrease phospho-FAK1. Our results suggest that combinational therapies could be more effective than using CEP-37440 as a single agent.

Keywords: CEP-37440, FAK1, ALK, IBC, Inflammatory breast cancer, Triple-negative breast cancer, TNBC

\footnotetext{
*Correspondence: Sandra.Fernandez@jefferson.edu

'Department of Medical Oncology, Thomas Jefferson University, Philadelphia,

PA, USA

Full list of author information is available at the end of the article
} 


\section{Background}

Inflammatory breast cancer (IBC) is a very aggressive type of advanced breast cancer with a poor prognosis. IBC occurs typically in patients under the age of 50 and is often misdiagnosed as an infection since it does not present as a lump [1]. The clinical symptoms of IBC involve the rapid onset of changes in the skin overlying the breast, including edema, redness, and swelling exhibiting a wrinkled, orange peel-like appearance of the skin known as peau d'orange [2]. This peculiar presentation is associated with the invasion of aggregates of tumor cells, defined as tumor emboli, into the dermal lymphatics, where they obstruct the lymph channels [3, 4]. Although IBC currently accounts for only 2-6\% of all breast cancer cases in the United States and up to $20 \%$ of all breast cancers globally [1, 5$7]$, its incidence is dramatically increasing $[2,4]$. Furthermore, due to its propensity to rapidly metastasize, IBC is responsible for a disproportionate number (15\%) of breast cancer-related deaths [7-9]. IBC is either stage III or IV disease, depending on whether cancer cells have spread only to nearby lymph nodes or to other tissues as well. At the time of diagnosis, most IBC patients have lymph node metastases, and approximately $30 \%$ have distant metastases in brain, bones, visceral organs, and soft tissue [1]. Currently, there is no adequate adjuvant therapy to reduce the risk of recurrence and mortality in IBC patients.

We recently found that focal adhesion kinase 1 (FAK1 or PTK2) is amplified, upregulated and phosphorylated (active) in IBC [10]. FAK1 is a nonreceptor tyrosine kinase that localizes to areas termed focal adhesions where the cell membrane attaches to the extracellular matrix. FAK1 activation relies upon autophosphorylation of the Tyr 397 site that is found in the N-terminal domain; FAK1 Tyr 397 binds various signaling proteins, including Src, PI-3 kinase, and Grb-7. FAK1 also binds epidermal growth factor receptor (EGFR), vascular epidermal growth factor receptor (VEGFR), p53, and other molecules that are critical for tumor growth and progression [11]. It controls various cellular pathways, including proliferation, viability, and survival, and its overexpression has been linked to anoikis resistance [12-15]. The activation and phosphorylation of FAK1 stimulated by many forms of oncogenic transformation provide a plausible mechanism for the anchorage-independent growth of cancer cells. FAK1 overexpression correlates negatively with patient outcome and is associated with increased cell migration, invasion, and metastasis; elevated FAK1 expression has been reported in multiple human epithelial tumors [14, 16-20].

CEP-37440 is a potent ATP-competitive, highly kinase selective, and orally active inhibitor of FAK1 (enzymatic $\mathrm{IC}_{50}: 2.3 \mathrm{nM}$, cellular $\mathrm{IC}_{50}: 88 \mathrm{nM}$ ) and anaplastic lymphoma kinase (ALK) (enzymatic $\mathrm{IC}_{50}: 3.5 \mathrm{nM}$, cellular $\mathrm{IC}_{50}: 40 \mathrm{nM}$, cellular $\mathrm{IC}_{50}$ in $75 \%$ human plasma: 120 $\mathrm{nM}$ ) [21]. In addition to a favorable metabolic stability and pharmacokinetic profile preclinically, CEP-37440 is also a brain penetrant [21]. In this study, we investigated the effect of CEP-37440 using human IBC cells and preclinical models of IBC. We found that CEP-37440 was able to inhibit the proliferation of certain IBC cells by decreasing the levels of phospho-FAK1 (Tyr 397); none of the cells expressed ALK. Studies using IBC xenograft models showed that CEP-37440 also effectively reduces the growth of the primary tumor xenografts and inhibits the development of brain metastases in mice.

\section{Methods}

Cell lines

The cell lines used are described in Table 1. The SUM149 and SUM190 cell lines were purchased from Asterand Inc.

Table 1 Sensitivity of the cell lines to CEP-37440

\begin{tabular}{|c|c|c|c|c|c|c|}
\hline \multirow[t]{2}{*}{ Cell line } & \multirow[t]{2}{*}{ Type } & \multicolumn{3}{|c|}{ Subtype } & \multirow[t]{2}{*}{$\mathrm{Gl}_{50}(\mathrm{nM})$} & \multirow[t]{2}{*}{ Reference } \\
\hline & & ESR & PgR & ErbB2 & & \\
\hline FC-IBC02 & $\mathrm{IBC}$ & Neg & Neg & Neg & 91 & {$[10]$} \\
\hline KPL4 & $\mathrm{IBC}$ & Neg & Neg & Post & $\sim 900$ & {$[41]$} \\
\hline SUM190 & $\mathrm{IBC}$ & Neg & Neg & Post & 890 & {$[42]$} \\
\hline MDA-IBC03 & $\mathrm{IBC}$ & Neg & Neg & Post & 1860 & {$[43]$} \\
\hline SUM149 & $\mathrm{IBC}$ & Neg & Neg & Neg & $>3000$ & {$[42]$} \\
\hline$M C F-12 A$ & Normal-like breast epithelial cells & Neg & Neg & Neg & 1516 & {$[44]$} \\
\hline MCA-10A & Normal-like breast epithelial cells & Neg & Neg & Neg & 1700 & {$[45]$} \\
\hline MDA-MB-231 & $B C$ (non-IBC) & Neg & Neg & Neg & 1930 & {$[46]$} \\
\hline MDA-MB-468 & $B C$ (non-IBC) & Neg & Neg & Neg & 1275 & {$[46]$} \\
\hline
\end{tabular}

Inflammatory breast cancer (IBC), breast cancer (BC) non-IBC, and normal-like breast epithelial cell lines were grown in the presence of different concentrations of CEP-37440 (cell proliferation assays). The $\mathrm{Gl}_{50}$ indicate the CEP-37440 concentration required to reduce growth rates to $50 \%$ of the maximum rate. The $\mathrm{Gl}$ 50 was calculated for each cell line at $t=144$ h of CEP-37440 treatment using sigmoidal dose response curve (variable slope) in GraphPad Prism (GraphPad Software Inc., La Jolla, CA, USA)

ESR estrogen receptor, PgR progesterone receptor, ErbB2 epidermal growth factor receptor 2 
(Detroit, MI, USA). The MDA-IBC03 cells were obtained from W.A. Woodward, and KPL4 cells were obtained from N.T. Ueno, The University of Texas MD Anderson Cancer Center, TX, USA. All other cell lines, MDA-MB-231, MDA-MB-468, MCF-10A, and MCF-12A, were purchased from American Type Culture Collection (ATCC; Manassas, VA, USA). The new model of IBC, designated as FCIBC02, was previously developed in our laboratory, through the isolation of tumor cells from the pleural effusion of an IBC patient, as described elsewhere [10].

\section{Reagents}

CEP-37440 was synthesized and provided by Teva Branded Pharmaceutical Products R\&D, West Chester, PA, USA. CEP-37440 has modest plasma protein binding, high intrinsic solubility, reduced lipophilicity, favorable microsomal metabolic stability across species, reduced capacity for drug-drug interaction, and possesses favorable oral bioavailability and a lower clearance rate in vivo across multiple species [21]. For in vitro assays, CEP-37440 free base was dissolved in dimethyl sulfoxide (DMSO) at concentration of $4 \mathrm{mM}$. For in vivo studies, CEP-37440 tri-hydrochloride di-hydrate salt was used and the drug was dissolved in distilled water. The media for the different cell lines are described in (Additional file 12).

\section{Total FAK1 and phospho-FAK1 (Tyr 397) assays}

Cells were grown to $80 \%$ confluence in $100 \mathrm{~mm}$ in diameter Petri dishes. Cells were collected in cold phosphate-buffered saline (PBS) by scraping from culture plates, centrifuged, and washed twice with cold PBS; proteins were extracted with $500 \mu \mathrm{l}$ of cell extraction buffer (Invitrogen, Life Technologies, Carlsbad, CA, USA) containing a mixture of protease inhibitors (Protease Inhibitors Cocktail, Sigma-Aldrich, St. Louis, MO, USA) and $1 \mathrm{mM}$ phenylmethanesulfonyl fluoride (PMSF). After extraction for $30 \mathrm{~min}$ on ice, the extracts were centrifuged at $14,000 \times \mathrm{g}$ for $10 \mathrm{~min}$ at $4{ }^{\circ} \mathrm{C}$, and the supernatant was transferred to a fresh microcentrifuge tube and kept at $-80{ }^{\circ} \mathrm{C}$ until use. The protein concentration in the cell extracts was determined using the BCA protein assay kit (Pierce, Rockford, IL, USA). Total FAK1 was studied in the cell protein extracts using FAK (Total) enzyme-linked immunosorbent assay (ELISA) kits (Invitrogen, Frederick, MD, USA); cell extracts were diluted 1:40 in dilution buffer as was recommended by the manufacturer; total FAK1 was expressed as ng total FAK $1 / \mu$ g protein. To study phospho-FAK1, FAK (pY397) ELISA kits (Invitrogen, Life Technologies, Carlsbad, CA, USA) were used and cell extracts were diluted 1:5 in dilution buffer; phospho-FAK1 (Y397) was expressed as units of phospho-FAK1/ $\mu$ g protein.

\section{Total ALK and phospho-ALK (Tyr 1604) assays}

Total ALK and phospho-ALK (Tyr 1604) were studied using PathScan Total ALK Sandwich ELISA and PathScan Phospho-ALK (Tyr 1604) Sandwich ELISA kits, respectively (Cell Signaling Technology, Inc., Danvers, MA, USA); protein extracts from Karpas 299 cells, a human T cell lymphoma cell line, were used as positive control.

\section{Cell proliferation assays}

For FC-IBC02, SUM190, MDA-IBC03, SUM149, MDAMB-231, MDA-MB-468, MCF-10A, and MCF-12A, a total of 2000 cells were plated per well in a 96-well plate, except for KPL4 in which 1000 cells were plated. After the cells were plated, they were allowed to attach overnight and then treated with CEP-37440 during several time points $(0 \mathrm{~h}, 24 \mathrm{~h}, 48 \mathrm{~h}, 72 \mathrm{~h}, 96 \mathrm{~h}, 120 \mathrm{~h}, 144 \mathrm{~h}$, $168 \mathrm{~h}$, and $192 \mathrm{~h})$. Several CEP-37440 concentrations were evaluated $(0,3,10,30,100,300,1000,2000$, and $3000 \mathrm{nM}$ ), and each concentration was tested in quadruplicate; as controls, cells growing in regular media (without CEP-37440) and media with 0.075 \% DMSO (vehicle) were included. After CEP-37440 treatments, the living cells were quantified using the CellTiter 96 Aqueous One Solution Cell Proliferation Assay kit (Promega, Madison, WI, USA) following the manufacturer's instructions. Briefly, the media with the CEP-37440 was removed, and $100 \mu \mathrm{l}$ of fresh media was added to each well; $20 \mu \mathrm{l}$ 3-(4,5-dimethylthiazol-2-yl)-5-(3-carboxymethoxyphenyl)2-(4-sulfophenyl)-2H-tetrazolium (MTS) compound was added and the cells were incubated at $37^{\circ} \mathrm{C}$ in a cell incubator for $4 \mathrm{~h}$. The absorbance at $490 \mathrm{~nm}$ and $630 \mathrm{~nm}$ (reference wavelength) was measured with a 96-well microplate reader (iMark ${ }^{\mathrm{mm}}$, Bio-Rad Laboratories Inc., Hercules, CA, USA).

\section{Gene expression profiling}

FC-IBC02 cells were treated with $1000 \mathrm{nM} \mathrm{CEP-37440} \mathrm{for}$ $48 \mathrm{~h}$ and RNA was isolated. Affymetrix Genechip Human Gene 1.0 ST array (Affymetrix Inc., Santa Clara, CA, USA) were used for gene expression studies (Additional file 12). Data analyses were performed using GeneSpring software 13.1 (Agilent Technologies, Inc., Santa Clara, CA, USA). The criteria for differentially expressed genes were set at $\geq$ 2.0 -fold changes. Statistical analysis was performed to compare two groups using $t$ test unpaired with a $p$ value less than or equal to 0.05 . A heat map was generated from the differentially expressed gene list. The list of differentially expressed genes was loaded into Ingenuity Pathway Analysis (IPA) 8.0 software (http://www.ingenuity.com) to perform biological network and functional analyses.

\section{In vivo studies using SCID mice}

Studies were approved by the Institutional Animal Care Committee at Thomas Jefferson University. A total of $10^{6}$ 
cells were suspended in $100 \mu \mathrm{l}$ PBS, mixed with $100 \mu \mathrm{l}$ Matrigel (BD Biosciences, Bedford, MA, USA), and injected into the fourth left inguinal mammary fat pad of severe combined immune-deficient (SCID) mice. The animals were palpated daily for detection of tumor development and, once the breast tumor xenografts reached approximately $50-100 \mathrm{~mm}^{3}$ (approximately 20-30 days postinjection), the mice were randomly allocated into groups. Two doses of CEP-37440 were tested for mice harboring FC-IBC02 or SUM149 breast tumor xenografts; the mice allocated to treatment received either $30 \mathrm{mg} / \mathrm{kg}$ twice a day (bid) or $55 \mathrm{mg} / \mathrm{kg}$ bid by oral gavage in a volume of $100 \mu \mathrm{l}, 5$ days/week for 35-40 days. For mice harboring SUM190 breast tumor xenografts, only the higher CEP-37440 dose (55 mg/kg bid) was tested. The CEP-37440 doses were chosen based on preliminary experiments in order to achieve an optimal plasma concentration-response relationship [21]. Breast tumors were measured using a vernier caliper, and tumor volumes were calculated using the following equation: $\mathrm{V}=[(\mathrm{L} 1+\mathrm{L} 2) / 2] \times \mathrm{L} 1 \times \mathrm{L} 2 \times 0.526$ where L1 and L2 are the length and width of the tumor. After 40 days of treatment or when the primary tumor reached a volume of approximately $1 \mathrm{~cm}^{3}$, the animals were euthanized by carbon dioxide $\left(\mathrm{CO}_{2}\right)$ inhalation. Breast tumors and other organs (lungs, heart, liver, spleen, brain, ovaries, kidneys, and lymph nodes) were removed, fixed in $10 \%$ neutral-buffered formalin and paraffin-embedded for histological examination (Additional file 12).

\section{Statistical analyses}

For the analyses of the cell proliferation data, the logtransformed response measures (Abs $490 \mathrm{~nm}$ and Abs $630 \mathrm{~nm}$ ) were modeled using the linear mixed effects (LME) model adjusting for correlations between repeated measures over time. The fixed effects included the ten concentrations and linear time trends. For the analyses of in vivo tumor growth data, the log-transformed tumor volumes were modeled using LME models adjusting for correlations between repeated measures from the same animal. The fixed effects included the control group and treatment groups $(30 \mathrm{mg} / \mathrm{kg}$ CEP-37440, and $55 \mathrm{mg} / \mathrm{kg}$ CEP-37440), and linear and quadratic time trends. The LME models included either only linear terms or both linear and quadratic terms as appropriate for specific time-dependent trends. Percent tumor growth inhibition (\% TGI) was calculated as follows: $100 \times[$ (tumor volume of the control group at the end of treatment tumor volume of the treated group at the end of the treatment)/tumor volume of the control group at the end of the treatment $]=100 \times(1-\exp$ (mean difference in log volumes at the end of the treatment), where the mean difference in $\log$ volumes at the end of the treatment was estimated from the fitted LME models. The data were analyzed using R package 'nlme' (The R Foundation for Statistical Computing http://www.Rproject.org).

\section{Results}

FAK1 is phosphorylated in IBC cell lines

Using ELISA, total FAK1 and phospho-FAK1 (Tyr 397) were studied in the IBC cell lines KPL4, MDA-IBC03, FC-IBC02, SUM190, and SUM149, and in the non-IBC triple-negative cell lines MDA-MB-231 and MDA-MB468. All of the cell lines expressed high levels of FAK1 (between $0.28 \mathrm{ng}$ to $0.7 \mathrm{ng} \mathrm{FAK} 1 / \mu \mathrm{g}$ protein), and no differences were observed between IBC and non-IBC cell lines (Fig. 1a). However, the levels of phospho-FAK1 (Tyr 397) differed between the cell lines (Fig. 1b). The percentage of phosphorylated FAK1 (Tyr 397) in relation of total FAK1 was higher in KPL4, MDA-MB-231 and MDA-MB-468 (Fig. 1c); $4.4 \%$ of total FAK1 was phosphorylated in KPL4, and approximately $3.6 \%$ was phosphorylated MDA-MB-231 and MDA-MB-468. A lower percentage of FAK1 was phosphorylated in FC-IBC02 (1.4 \%), SUM149 (1.4\%), SUM190 (0.66\%), and MDAIBC03 (0.54 \%) (Fig. 1c). We also studied the expression of FAK1 and phospho-FAK1 in the human normal-like breast epithelial cells MCF-10A and MCF-12A; these cells express FAK1 (approximately $0.5 \mathrm{ng}$ total FAK1/ $\mu \mathrm{g}$ protein and $0.26 \mathrm{ng}$ total $\mathrm{FAK} 1 / \mu \mathrm{g}$ protein, respectively) but they did not express phospho-FAK1 (Tyr 397).

\section{ALK was not expressed by IBC cell lines}

The IBC cell lines FC-IBC02, SUM190, KPL4, SUM149 and MDA-IBC03 were tested for expression of ALK by ELISA. The human $\mathrm{T}$ cell lymphoma cell line Karpas 299 that carries the NPM (nucleophosmin)-ALK fusion gene was used as positive controls and these cells were strongly positive for total ALK and phospho-ALK (Tyr 1604). All of the IBC cell lines tested were negative for total ALK and phospho-ALK (Tyr 1604), and the nonIBC cell lines MDA-MB-231 and MDA-MB-468 were also negative for total ALK and phospho-ALK expression (data not shown).

\section{CEP-37440 specifically decreased the proliferation of certain IBC cells in a concentration-dependent manner} Cell proliferation rate was studied in the IBC cell lines in the presence of several concentrations of CEP-37440. The MTS assay that measures cellular respiration was used as a surrogate of cell proliferation. In the presence of 300 nM CEP-37440, FC-IBC02 significantly decreased in proliferation compared to the control without the drug, and 1000 nM CEP-37440 completely inhibited FCIBC02 proliferation, killing these cells after $72 \mathrm{~h}$ of treatment (Fig. 2a). FC-IBC02 showed a positive linear 


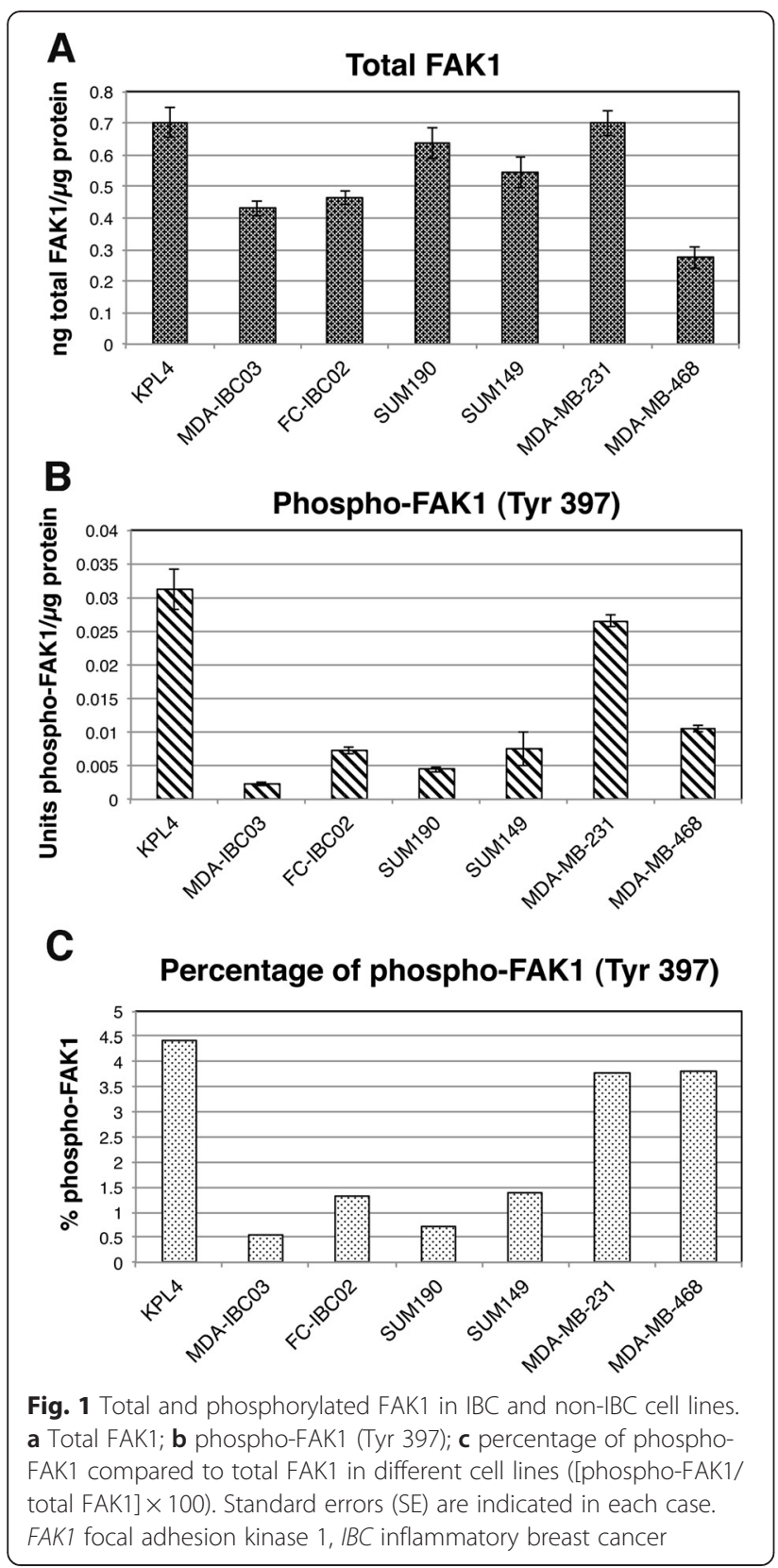

growth rate when the cells were in the presence of lower concentrations of CEP-37440 (3 nM, $10 \mathrm{nM}, 100 \mathrm{nM}$ and $300 \mathrm{nM}$ ) (Additional file 1: Figure S1 and Additional file 2: Table S1); in contrast, the growth rates in the cells treated with high concentrations of CEP-37440 (1000 nM, $2000 \mathrm{nM}$ and $3000 \mathrm{nM}$ ) were not significantly different from time 0 (Additional file 1: Figure S1 and Additional file 2: Table S1).

In KPL4 cells, treatment with $1000 \mathrm{nM} \mathrm{CEP-37440} \mathrm{for}$ $144 \mathrm{~h}$ reduced significantly the proliferation of cells compared to the control, and the growth rate was even lower in the presence of $2000 \mathrm{nM}$ or $3000 \mathrm{nM}$ CEP-37440 (Fig. 2b). The growth rate in the KPL4 cells treated with the $3000 \mathrm{nM}$ CEP-37440 was the lowest (Additional file 3: Figure S2 and Additional file 4: Table S2).

In SUM190 cells, treatment with $1000 \mathrm{nM}$ CEP-37440 for $144 \mathrm{~h}$ reduced proliferation to approximately $60 \%$ (Fig. 2c). The response measures corresponding to all concentrations except for $3000 \mathrm{nM}$ grew over time and were significantly different from zero rates (Additional file 5: Figure S3 and Additional file 6: Table S3). The IBC cell line MDA-IBC03 only responded to a very high concentration of CEP-37440 (Fig. 2d), and SUM149 showed a slight response to high CEP-37440 concentrations (Fig. 2e). We also tested the effect of CEP-37440 on the triple-negative non-IBC cell lines MDA-MB-231 and MDA-MB-468 (Fig. 3a and b). Treatment with 2000 $\mathrm{nM}$ CEP-37440 for $144 \mathrm{~h}$ reduced MDA-MB-231 and MDA-MB-468 proliferation to approximately 46-54\% (Fig. 3a, 3b). We also studied the potential cytotoxic effects of CEP-37440 on normal breast epithelial cells, MCF-10A and MCF-12A (Fig. 3c and d). We found that $300 \mathrm{nM}$ or $1000 \mathrm{nM}$ CEP-37440 did not affect the proliferation of these cells; 2000 nM CEP-37440 decreased their proliferation to approximately $50 \%$ and $3000 \mathrm{nM}$ CEP-37440 inhibited their proliferation almost completely (Fig. 3c, 3d). The drug concentration required to reduce growth rates to $50 \%\left(\mathrm{GI}_{50}\right)$ for each cell line are shown in Table 1.

In conclusion, CEP-37440 at low concentration specifically reduced the proliferation of three out of five IBC cell lines; FC-IBC02, KPL4 and SUM190 cells showed decreased proliferation in the presence of $1000 \mathrm{nM}$ CEP37440 , and this same concentration did not significantly reduce the proliferation of normal breast epithelial cells. The CEP-37440 concentrations required to reduced the growth rate to $50 \%\left(\mathrm{GI}_{50}\right)$ for each cell line are indicated in Table 1. The sensitivity of these IBC cell lines to CEP37440 was not related to the cell subtype since FC-IBC02 is a triple-negative cell line, and KPL4 and SUM190 are human epidermal growth factor receptor 2; (ErbB2)-positive (Table 1). MDA-IBC03 and the triple-negative nonIBC cell lines MDA-MB231 and MDA-MB-468 were less sensitive to CEP-37440, and the IBC cell line SUM149 was slightly affected by the drug.

CEP-37440 decreases phospho-FAK1 (Tyr 397) and maintains its low level over time in FC-IBC02, SUM 190, and KPL4

To test the effect of CEP-37440 on the autophosphorylation of FAK1 and its Tyr 397 site, IBC cell lines were treated with $1000 \mathrm{nM}$ CEP-37440 during different time intervals $(0 \mathrm{~h}, 48 \mathrm{~h}, 72 \mathrm{~h}, 96 \mathrm{~h}$, and $120 \mathrm{~h})$ and total FAK1 and phospho-FAK1 (Tyr 397) were studied (Fig. 4). In FC-IBC02 cells treated with CEP-37440, the levels of total FAK1 were similar compared to the control without treatment ( $0.5 \mathrm{ng}$ to $0.6 \mathrm{ng}$ total $\mathrm{FAK} 1 / \mu \mathrm{g}$ protein) (Fig. 4a), but the levels of phospho-FAK1 decreased over 

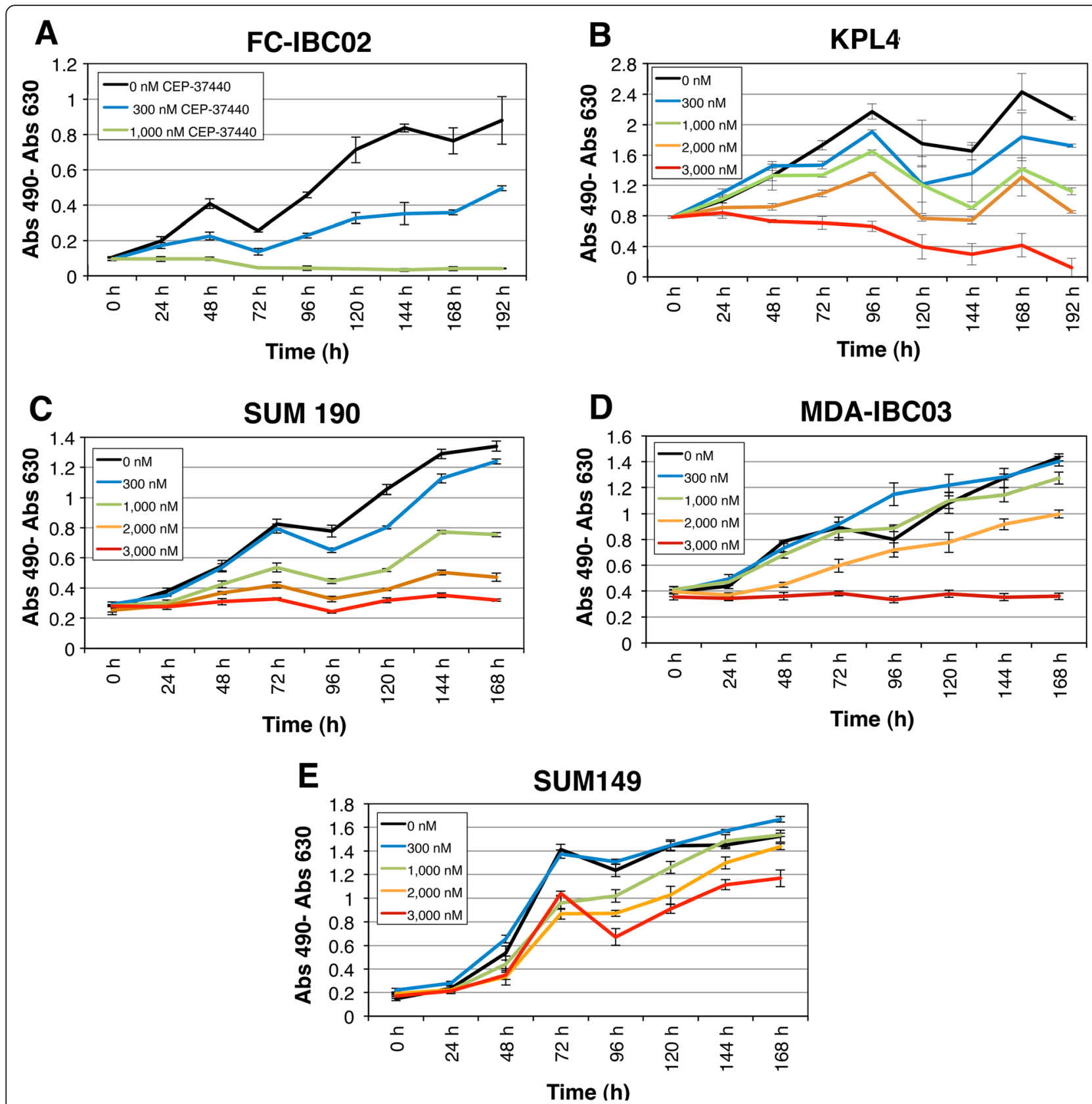

Fig. 2 Effect of CEP-37440 on IBC cell lines proliferation. Several concentrations of CEP-37440 were tested on the IBC cell lines: a FC-IBC02, b KPL4, c SUM190, d MDA-IBC03, and e SUM149. CEP-37440 at low concentration (1000 nM) inhibited the proliferation of the IBC cells FC-IBC02, KPL4 and SUM190 but did not affect MDA-IBC03 and SUM149 proliferation. At higher concentration, 3000 nM CEP-37440, inhibited MDA-IBC03 proliferation. CEP-37440 did not inhibit SUM149 proliferation. Each point in the graphic represents the mean \pm standard errors (SE) of four replicates. IBC inflammatory breast cancer

time in the cells treated with CEP-37440, reaching a

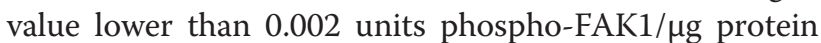
at 72 to $120 \mathrm{~h}$ of treatment (Fig. 4b). In SUM190 cells, the levels of total FAK1 decreased to approximately $50 \%$ in the cells treated with $1000 \mathrm{nM}$ of CEP-37440 compared to the control without treatment (Fig. 4a), and the phospho-FAK1 (Tyr 397) decreased from 0.07

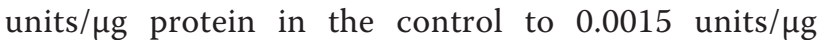

protein in the CEP-37440-treated cells after 48 to $120 \mathrm{~h}$ of treatment (Fig. 4b). In both FC-IBC02 and SUM190 cells, the levels of phospho-FAK1 (Tyr 397) reached similar levels $(0.0015$ to $0.002 \mathrm{units} / \mu \mathrm{g}$ pro-

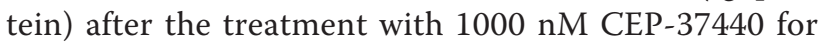
$48 \mathrm{~h}$ (Fig. 4b).

In KPL4 cells, the levels of total FAK1 were similar between cells treated with CEP-37440 and the control 

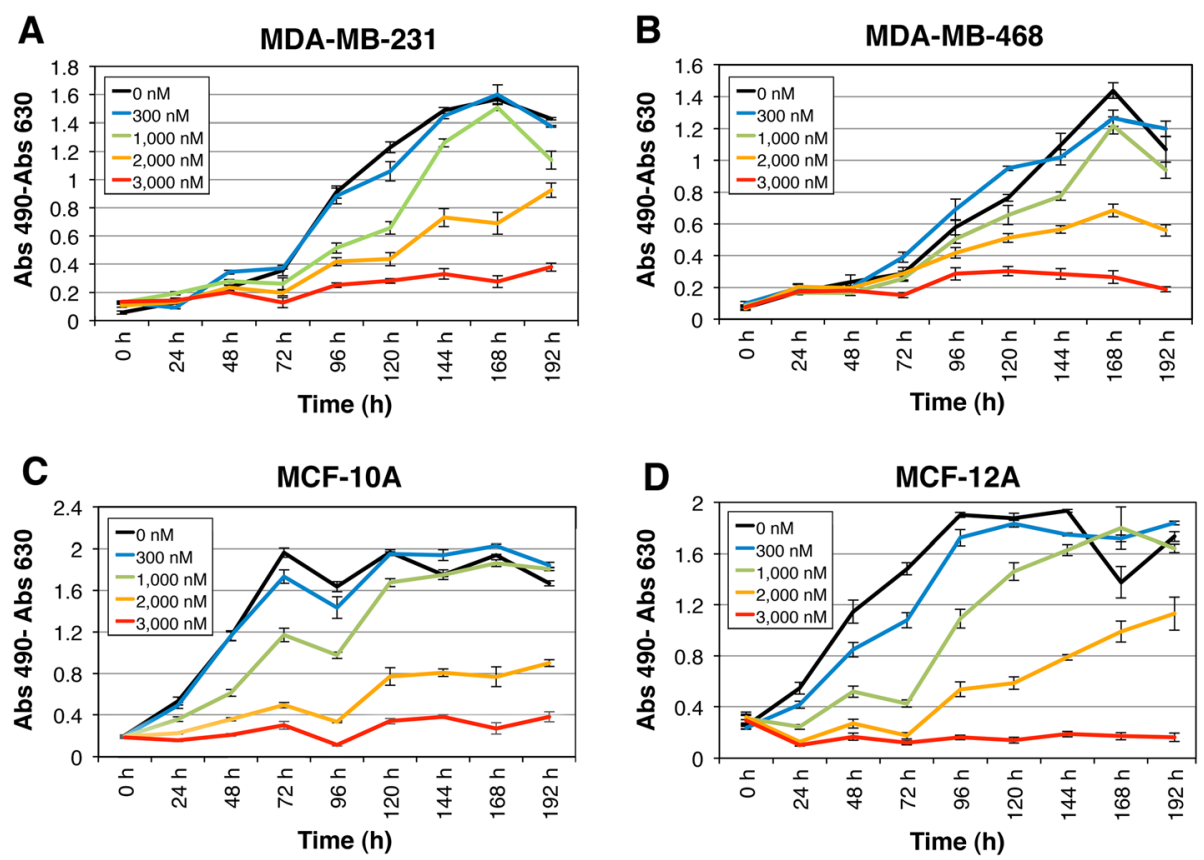

Fig. 3 Effect of CEP-37440 on the proliferation of non-IBC breast tumor cells and normal breast epithelial cells. Several concentrations of CEP37440 were tested on the cell lines: a MDA-MB-231, b MDA-MB-468, c MCF-10A and d MCF-12A. CEP-37440 at high concentration inhibited the proliferation of the triple-negative non-IBC cell lines MDA-MB-231 and MDA-MB-468 but, also decreased the proliferation of normal breast epithelial cells. A concentration of 3000 nM CEP-37440 inhibited MDA-MB-231 and MDA-MB-468 proliferation but also inhibited the proliferation of the normal-like breast epithelial cells MCF-10A and MCF-12A. Each point in the graphic represents the mean \pm standard errors (SE) of four replicates. IBC inflammatory breast cancer

without treatment (Fig. 4a), however, there was a significant decrease in phospho-FAK1 (Tyr 397) after CEP-37440 treatment from $2.5 \%$ in the control without treatment to $1.4 \%$ in cells treated with CEP-37440 (Fig. 4b and 4c). In SUM149, the levels of total FAK1 in treated cells were similar to the control during the first $72 \mathrm{~h}$ of treatment, decreasing from $0.4-0.2 \mathrm{ng}$ total FAK1/ $\mu \mathrm{g}$ protein after 96-120 h of CEP-37440 treatment (Fig. 4a); however there was a slightly decrease of phospho-FAK1, decreasing from 0.019 Units phospho-FAK1/ $\mu \mathrm{g}$ protein in the control to 0.008-0.009 Units phospho-FAK1/ $\mu \mathrm{g}$ protein at 96-120 $\mathrm{h}$ of CEP-37440 treatment (Fig. 4b). In SUM149, there was a decrease from $4.9 \%$ phospho-FAK1 in the control without treatment to $3.8 \%$ phospho-FAK1 after $120 \mathrm{~h}$ of CEP37440 treatment (Fig. 4c).

In conclusion, low concentration of CEP-37440 (1000 $\mathrm{nM})$ was able to decreased phospho-FAK1 by half in FC-IBC02, SUM190, and KPL4 cells after $48 \mathrm{~h}$ of treatment compared to the controls without treatment, while in SUM149, it only decreased slightly.

\section{Expression arrays analyses of FC-IBC02 cells treated with CEP-37440}

FC-IBC02 IBC cells were selected for expression array analyses because our previous results showed that CEP37440 at low concentration (1000 nM) was able to completely inhibit the proliferation of these cells in vitro. Cells were treated with $1000 \mathrm{nM}$ CEP-37440 for $48 \mathrm{~h}$, RNA was isolated from the cells, and expression studies were performed. The microarray data have been deposited into the NCBI's gene expression omnibus (GEO) data sets (GSE73285). A total of 43 genes showed changes in their expression when cells were treated with CEP-37440 compared to the control (2.0-fold, $p=0.05$ ), with ten downregulated and 33 upregulated genes (Fig. 5 and Table 2). Using IPA, the major functions affected by CEP-37440 were cell death and survival, cellular growth and proliferation, and motility. Among key upregulated genes, those related to interferon signaling and cytokines were upregulated as follows: IFI27 (4.3-fold), IFI6 (3.5-fold), IFI35 (2.4fold), IRF7 (2.1-fold), CCL5 (4.6-fold), IL32 (3.6-fold), and IL23A (2.1-fold). Similarly, the expression of interferonstimulated genes was upregulated, as well: OAS2 (5.8fold), OAS3 (3.5-fold), OAS1 (3.3-fold), MX1 (2.6-fold), and ISG15 (2.4-fold). CEP-37440 upregulated two other genes related to cell death and survival: BIK (2.3-fold) and KDR (2.3-fold).

\section{CEP-37440 inhibited breast tumor growth in the IBC breast tumor xenograft models}

CEP-37440 was tested in vivo using the triple-negative FC-IBC02 and SUM149 and the ErbB2-positive SUM190 


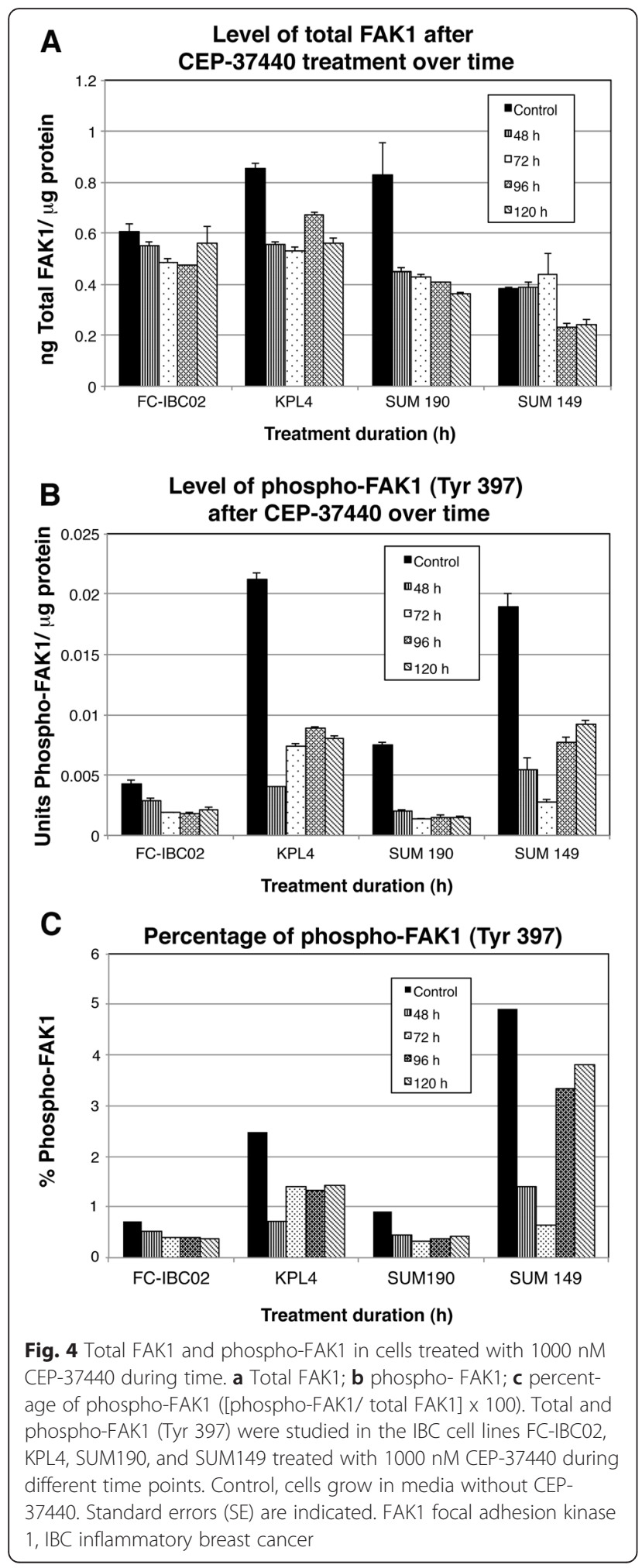

IBC breast xenograft models. The IBC cells were injected in the mammary fat pad of female SCID mice, and treatment with CEP-37440 began once the breast tumor xenografts reached approximately $50-100 \mathrm{~mm}^{3}$.

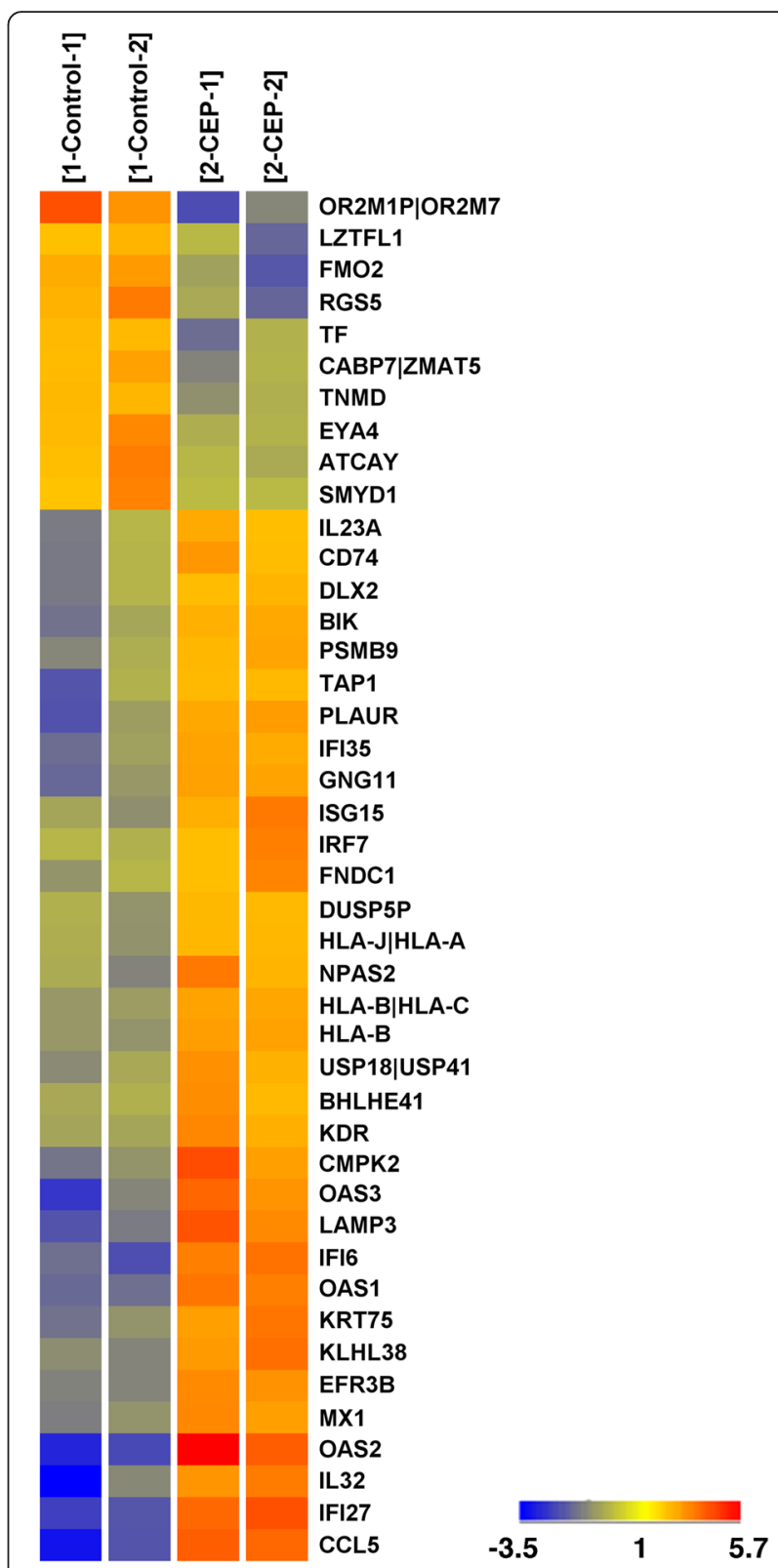

Fig. $\mathbf{5}$ Heat map of FC-IBC02 cells treated with CEP-37440. FC-IBC02 cells were treated with 1000 nM CEP-37440 for 48 h, RNA was isolated and expression arrays were performed. RNA isolate from FC-IBC02 without treatment was used as control. Red, yellow and blue colors indicate levels above, at, and below mean expression, respectively. In the color scale, fold induction values are indicated

All of the mice injected with FC-IBC02 or SUM149 developed breast tumor xenografts, and two doses of CEP$37440(30 \mathrm{mg} / \mathrm{kg}$ and $55 \mathrm{mg} / \mathrm{kg})$ were tested in these mice. In the animals harboring FC-IBC02 breast tumor xenografts, mice treated with $55 \mathrm{mg} / \mathrm{kg}$ bid CEP-37440 showed smaller tumor breast xenografts compared to the control group that did not receive the drug (Fig. 6). The breast tumor growth was significantly lower in the 
Table 2 Genes dysregulated in FC-IBC02 cells by CEP-37440

\begin{tabular}{|c|c|c|c|}
\hline Gene symbol & Gene description & Fold induction & $p$ value \\
\hline IFI27 & Interferon, alpha-inducible protein 27 & 4.3 & 0.002 \\
\hline IFl6 & Interferon, alpha-inducible protein 6 & 3.5 & 0.003 \\
\hline IFI35 & Interferon-induced protein 35 & 2.4 & 0.013 \\
\hline IRF7 & Interferon regulatory factor 7 & 2.1 & 0.036 \\
\hline CCL5 & Chemokine ligand 5 (Rantes) & 4.6 & 0.008 \\
\hline IL32 & Interleukin 32 & 3.6 & 0.044 \\
\hline IL23A & Interleukin 23, alpha subunit P19 & 2.1 & 0.028 \\
\hline OAS2 & 2'-5'-oligoadenylate synthetase 2, 69/71 kDa & 5.8 & 0.016 \\
\hline OAS3 & 2'-5'-oligoadenylate synthetase 3, $100 \mathrm{kDa}$ & 3.5 & 0.022 \\
\hline OAS1 & 2'-5'-oligoadenylate synthetase 1, 40/46 kDa & 3.3 & 4.70E-04 \\
\hline MX1 & MX dynamin-like GTPase 1 & 2.6 & 0.005 \\
\hline ISG15 & ISG15 ubiquitin-like modifier & 2.4 & 0.021 \\
\hline BIK & BCL2-interacting killer (apoptosis-inducing) & 2.3 & 0.016 \\
\hline KDR & Kinase insert domain receptor & 2.3 & 0.012 \\
\hline LAMP3 & Lysosomal-associated membrane protein 3 & 3.6 & 0.013 \\
\hline CMPK2 & Cytidine monophosphate kinase 2 & 3.0 & 0.03 \\
\hline KLHL38 & Kelch-like family member 38 & 2.8 & 0.009 \\
\hline EFR3B & EFR3 homolog B & 2.8 & $3.14 \mathrm{E}-04$ \\
\hline KRT75 & Keratin 75, type II & 2.8 & 0.013 \\
\hline GNG11 & Guanine nucleotide-binding protein, gamma 11 & 2.6 & 0.010 \\
\hline PLAUR & Plasminogen activator, urokinase receptor & 2.6 & 0.024 \\
\hline$H L A-B$ & Major histocompatibility complex, class I, B & 2.4 & $2.50 \mathrm{E}-04$ \\
\hline NPAS2 & Neuronal PAS domain protein 2 & 2.4 & 0.031 \\
\hline HLA-B|HLA-C & Major histocompatibility complex, & 2.3 & $2.38 \mathrm{E}-04$ \\
\hline TAP1 & Transporter 1, ATP-binding cassette, sub-family B & 2.3 & 0.048 \\
\hline USP18|USP41 & Ubiquitin specific peptidase 18/41 & 2.3 & 0.013 \\
\hline FNDC1 & Fibronectin type III domain-containing 1 & 2.2 & 0.033 \\
\hline CD74 & CD74 molecule & 2.2 & 0.03 \\
\hline PSMB9 & Proteasome subunit, beta type, 9 & 2.2 & 0.013 \\
\hline BHLHE41 & Basic helix-loop-helix family, member E41 & 2.1 & 0.018 \\
\hline DLX2 & Distal-less homeobox 2 & 2.1 & 0.025 \\
\hline DUSP5P & Dual specificity phosphatase 5 pseudogene 1 & 2.0 & 0.007 \\
\hline HLA-J|HLA-A & Major histocompatibility complex & 2.0 & 0.007 \\
\hline OR2M1P|OR2M7 & Olfactory receptors & -3.5 & 0.023 \\
\hline FMO2 & Flavin containing monooxygenase 2 & -2.6 & 0.026 \\
\hline RGS5 & Regulator of $\mathrm{G}$ protein signaling 5 & -2.6 & 0.036 \\
\hline TF & Transferrin & -2.2 & 0.031 \\
\hline CABP7 & Calcium-binding protein 7 & -2.2 & 0.021 \\
\hline LZTFL1 & Leucine zipper transcription factor-like 1 & -2.2 & 0.044 \\
\hline ATCAY & Ataxia, cerebellar, Cayman type & -2.1 & 0.038 \\
\hline EYA4 & EYA transcriptional coactivator and phosphatase 4 & -2.1 & 0.023 \\
\hline SMYD1 & SET and MYND domain-containing 1 & -2.0 & 0.041 \\
\hline TNMD & Tenomodulin & -2.0 & 0.007 \\
\hline
\end{tabular}

Cells were treated with $1000 \mathrm{nM}$ CEP-37440 during $48 \mathrm{~h}$ and expression studies were performed 


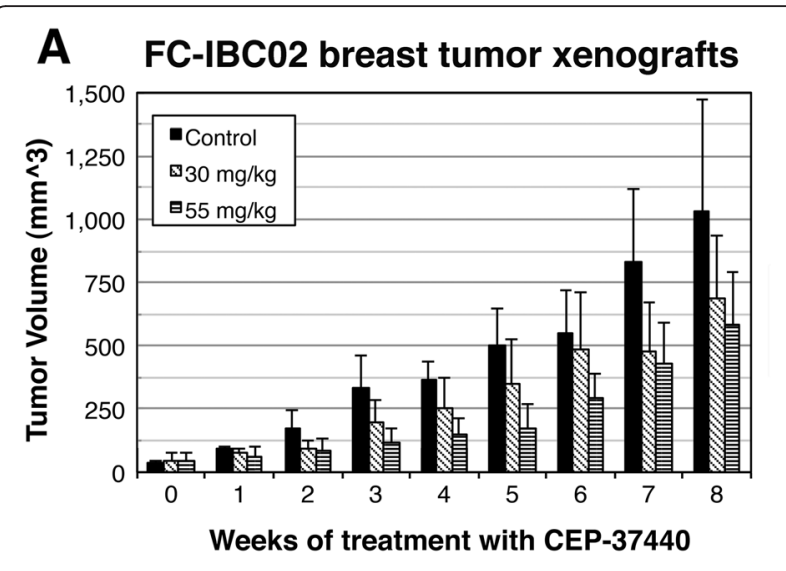

\section{B Weight of mice with FC-IBC02 breast tumor xenografts}

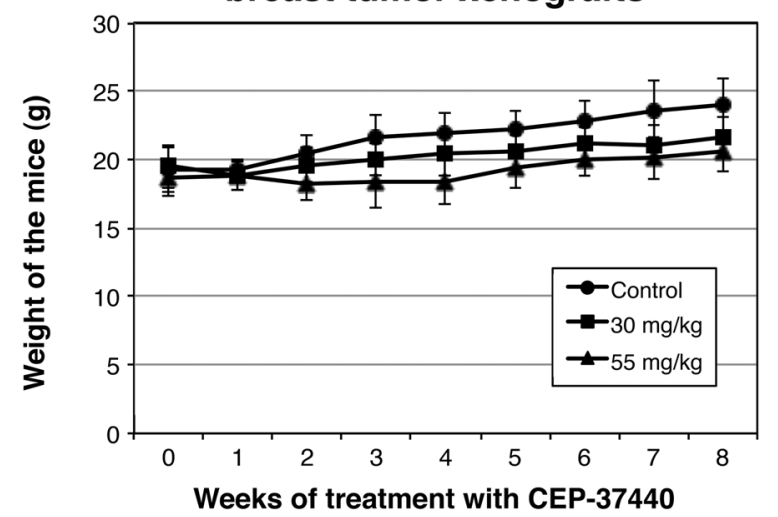

Fig. 6 In vivo studies: effect of CEP-37440 on mice with FC-IBC02 breast tumor xenografts. Mice were injected with $10^{6}$ FC-IBC02 cells in the mammary fat pad; when the breast tumor xenografts reached approximately $50 \mathrm{~mm}^{3}$, treatments with CEP-37440 began. Treatments with CEP-37440 were performed twice a day during 8 weeks. a Volumes of breast tumor xenografts in the control group (without treatment) or mice treated with $30 \mathrm{mg} / \mathrm{kg}$ or $55 \mathrm{mg} / \mathrm{kg}$ CEP-37440; b weights of the mice in the different groups. Standard deviations (StDEV) are indicated

group treated with $55 \mathrm{mg} / \mathrm{kg}$ bid CEP-37440 than the control group without treatment over the 7-week study $(p \leq 0.001)$ (Additional file 7: Figure S4 and Additional file 8: Table S4). Also, mice treated with $55 \mathrm{mg} / \mathrm{kg}$ bid showed smaller tumors than the mice treated with $30 \mathrm{mg} / \mathrm{kg}$ bid CEP-37440 over the entire duration of the study (Additional file 7: Figure S4). At the end of the study, there was approximately $33 \%$ reduction in the FC-IBC02 breast tumor xenograft size after the mice were treated with $55 \mathrm{mg} / \mathrm{kg}$ bid CEP-37440 (week 8; 40 days of treatment) (Fig. 6a) $(p=0.128)$. Furthermore, there was approximately $21 \%$ reduction in the FC-IBC02 breast tumor xenografts size after the mice were treated with $30 \mathrm{mg} / \mathrm{kg}$ bid CEP-37440 at week 8 (40 days of treatment) $(p=0.380)$ (Fig. 6a). FC-IBC02 mice treated with CEP-37440 showed no signs of toxicity, such as hair loss or significant weight loss compared to the control group without treatment (Fig. 6b). Importantly, although our previous experiments showed that $20 \%$ of the mice with FC-IBC02 breast xenografts developed spontaneous metastatic brain tumors (Fig. 7c), none of the mice treated with CEP-37440 (30 mg/kg or $55 \mathrm{mg} / \mathrm{kg}$ ) developed brain tumors. No differences in the number of metastatic sites in the lungs were found when comparing the $55 \mathrm{mg} /$ $\mathrm{kg}$ CEP-37440-treated mice (Fig. 7e) and the control group (Fig. 7b) .

In animals harboring SUM149 breast tumor xenografts, mice treated with CEP-37440 showed smaller tumor breast xenografts compared to the control group that did not receive the drug (Fig. 8a). The breast tumor growth was significantly lower in the mice treated with CEP-37440 than in the control group without treatment over the 7-week study, although the growth of the tumors was lower in the mice treated with $30 \mathrm{mg} / \mathrm{kg}$ bid than with $55 \mathrm{mg} / \mathrm{kg}$ bid CEP-37440 (Additional file 9: Figure S5 and Additional file 10: Table S5). At the end of the study (week 7, 35 days of treatment), there was approximately $43 \%$ reduction in the SUM149 breast tumor xenograft size after the mice were treated with $30 \mathrm{mg} / \mathrm{kg}$ bid CEP-37440 $(p=0.021)$ and approximately $23 \%$ reduction in the SUM149 breast tumor xenografts size after the mice were treated with $55 \mathrm{mg} / \mathrm{kg}$ bid CEP37440 at week $7 \quad(p=0.302)$. SUM149 breast tumor xenograft mice treated with CEP-37440 showed no significant weight loss compared to the control group that was not treated with CEP-37440 (Fig. 8b).

CEP-37440 was also tested in mice harboring SUM190 ErbB2-positive breast tumor xenografts. A significant difference in the size of the SUM190 breast tumor xenografts was observed in the treated group when compared to mice in the control group that did not receive the drug (Fig. 9a). There was 79.7 \% reduction in the SUM190 breast tumor xenograft size after the mice were treated with $55 \mathrm{mg} / \mathrm{kg}$ bid CEP-37440 for 35 days (week 7) $(p=0.001)$ (Additional file 11: Table S6). There were no significant differences between the weight of the control and CEP-37440-treated mice (Fig. 9b).

\section{Discussion}

Our studies showed that low concentrations of CEP37440 specifically decreased the proliferation of the IBC cell lines FC-IBC02, SUM190, and KPL4 without affecting proliferation of normal breast epithelial cells. These IBC cells were sensitive to low concentrations of CEP37440 and their sensitivity was independent of the cell subtype (triple-negative or ErbB2-positive). At higher concentrations, CEP-37440 also inhibited the proliferation of the IBC cell line MDA-IBC03 and the triplenegative non-IBC cell lines MDA-MB-231 and MDA- 


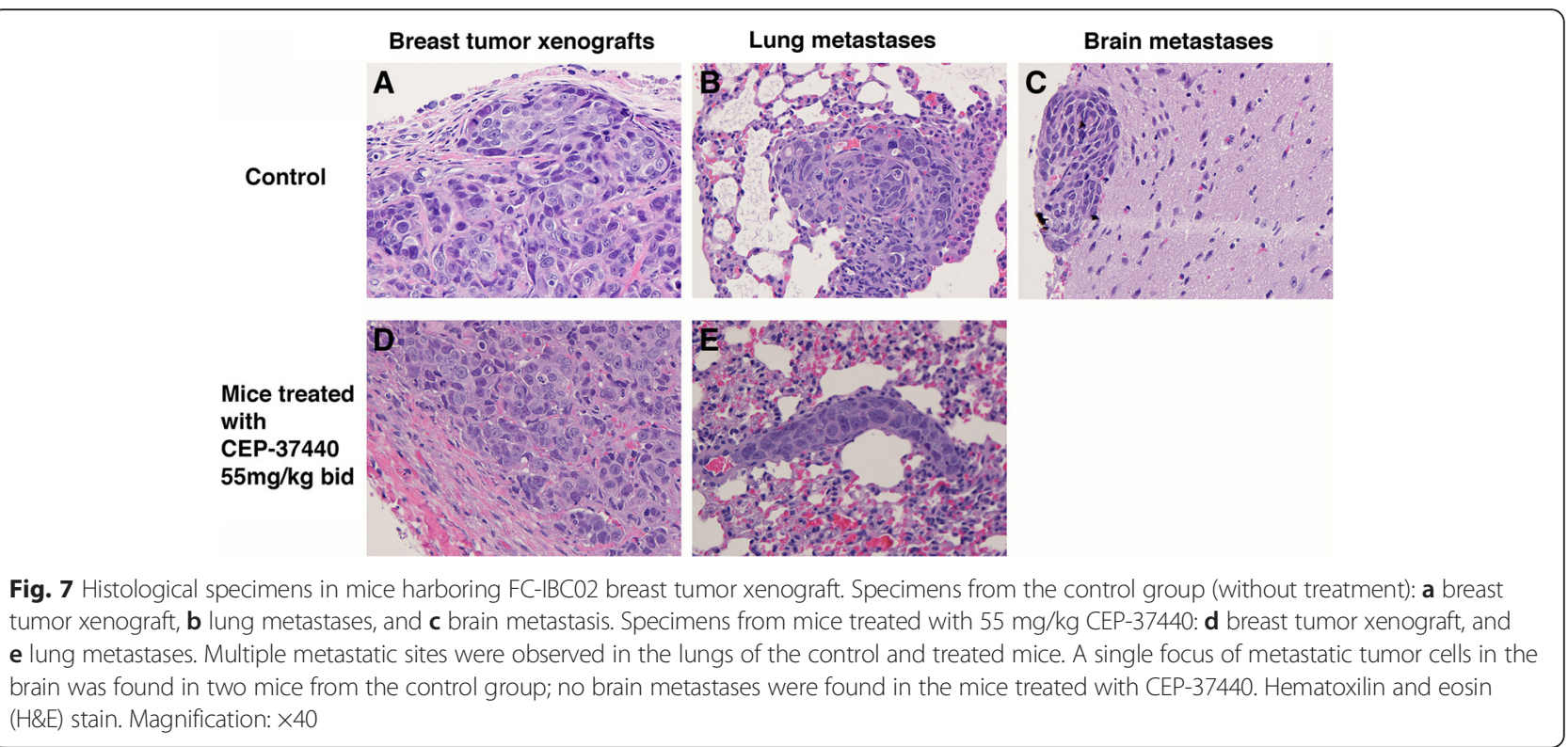

MB-468. Since CEP-37440 is a dual inhibitor of FAK1 and ALK, we studied the expression of both proteins in the IBC cell lines and found that they expressed FAK1 but not ALK. We demonstrated that CEP-37440 decreased the cell proliferation of FC-IBC02, SUM190, and KPL4 by blocking the autophosphorylation kinase activity of FAK1 (Tyr 397).

We previously showed that IBC cells exhibit amplification of the chromosomal arm 8q where FAK1 is located (8q24.3) [10]. However, gene expression studies using arrays did not show any correlation between copy number and RNA expression in these IBC cell lines [10]. Furthermore, our present work did not find a correlation between elevated total FAK1 expression at the protein level and FAK1 gene amplification in either IBC cells or triple-negative non-IBC cell lines. Increased dosage of the FAK1 gene is invariantly observed in the cell lines derived from human cancers of lung, breast, colon, and invasive squamous cell carcinomas [22]. However, elevated FAK1 protein expression is not always correlated with amplification of the FAK1 gene. In human head and neck squamous cell carcinoma, not all cases with an amplification of the FAK1 gene display FAK1 protein overexpression, implicating a sophisticated posttranscriptional regulation involved in FAK1 expression and function [23].

In vivo studies showed that CEP-37440 significantly decreased breast tumor growth in the SUM190 and FC-IBC02 mouse xenograft models, and the tumor growth inhibition was dose and time dependent. Mice harboring SUM190 and FC-IBC02 breast tumor xenografts showed $79.7 \%$ and $33 \%$ TGI, respectively, when treated with $55 \mathrm{mg} / \mathrm{kg}$ bid CEP-37440 for 3540 days. The tumor breast xenografts of mice treated with CEP-37440 showed lower levels of phosphoFAK1 (Tyr 397) than the breast tumor xenografts in the control groups (data not shown). Although the IBC cell line SUM149 showed in vitro only a slight response to high concentrations of the drug, CEP37440 reduced the size of the primary tumor in the mice harboring SUM149 breast tumor xenografts, and results were better with $30 \mathrm{mg} / \mathrm{kg}$ bid than $55 \mathrm{mg} / \mathrm{kg}$ bid CEP-37440. Since there was no total regression of the primary tumor or metastatic sites in the lungs in mice harboring IBC xenografts, our results suggest that a combination therapy approach would be more effective for IBC patients than CEP-37440 alone. Preclinical studies showed that the combination therapy approach using inhibitors of FAK1 with other signaling pathways increased the efficacy of single inhibitors $[22,23]$. These types of combinatorial studies have not been conducted with CEP-37440 in preclinical models of IBC or triple-negative breast cancer (TNBC).

None of the FC-IBC02 breast xenograft mice treated with CEP-37440 developed brain metastases in contrast to $20 \%$ in the control group. This data suggests that CEP-37440 is able to cross the blood-brain barrier. Related work by another group found that TAE226, another small molecule inhibitor targeting the ATPbinding site of FAK1, increased apoptosis of glioblastoma, an infiltrative brain tumor, and inhibited tumor growth [24].

The overexpression and phosphorylation of FAK1 on Tyr 397 is frequently associated with tumor metastasis as well as poor patient prognosis [25-28], indicating a critical role for activated FAK1 in tumor progression and malignancy. Tyrosine 397 is the main autophosphorylation site of FAK1, leading to activation of its intrinsic 


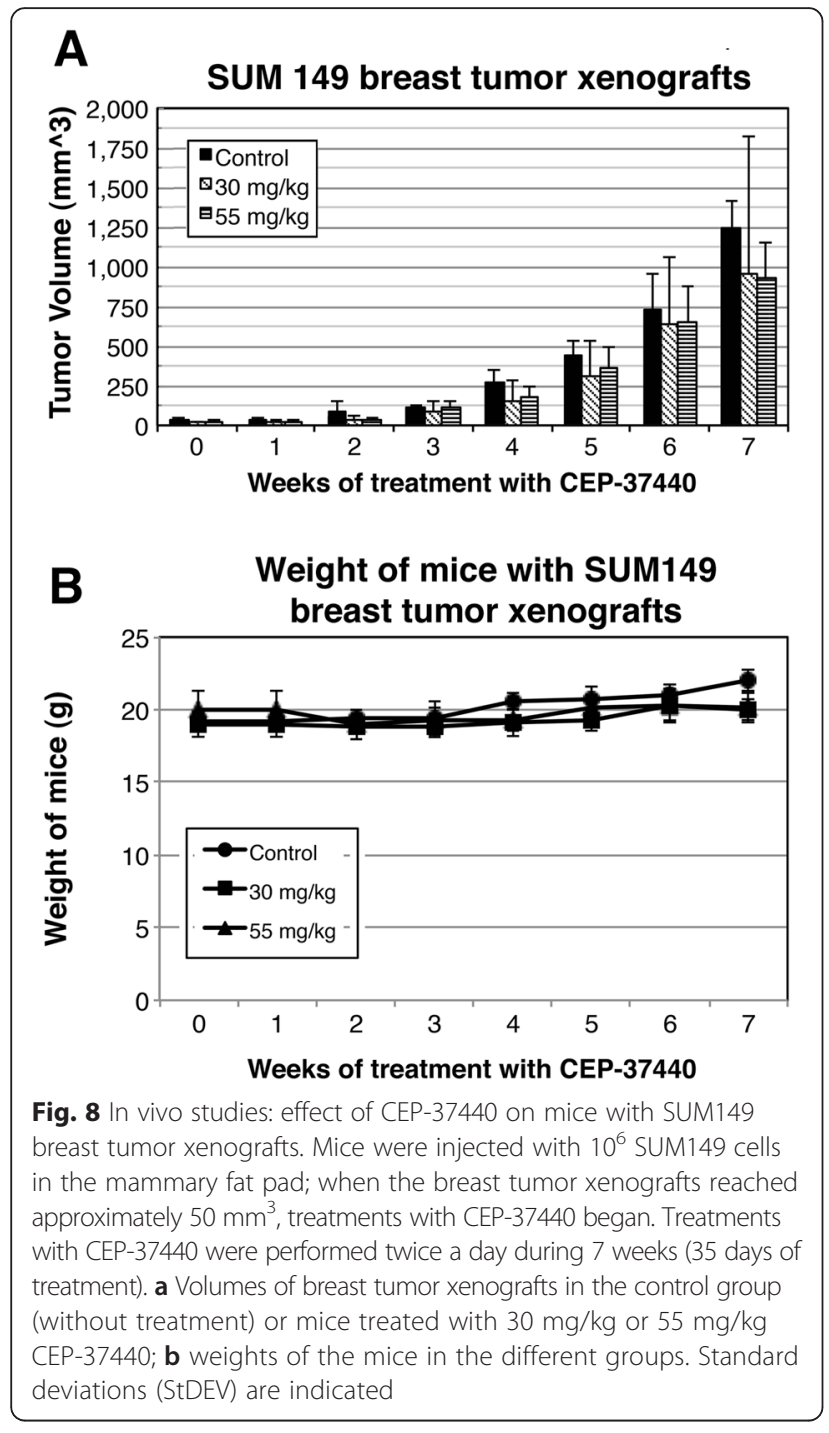

kinase function as well as its downstream signaling players, and providing a high-affinity binding site for the SH2 domain of Src family kinases [29, 30]. Furthermore, phospho-FAK1 binds to the p85 subunit of phosphatidylinositol 3-kinase (PI3K) at the Tyr 397 autophosphorylation site. Phospholipid production stimulated by phospho-FAK1 and activation of PIK3 can stimulate AKT kinase, which inhibits apoptosis by regulating various cell death cascade proteins [31]. In addition to its roles as a cytoplasmic kinase, recent studies revealed that FAK1 can translocate to the nucleus where it can influence the expression of chemokines, which are secreted to the surrounding environment [32]. These proteins recruit regulatory $\mathrm{T}$ cells (Treg) into tumors, which in turn suppress the CD8 antitumor response. Therefore, nuclear FAK1 signaling in cancer cells can help establish an environment within the tumor that supports survival and growth. FAK1 kinase inhibitors target mechanisms of immune suppression and

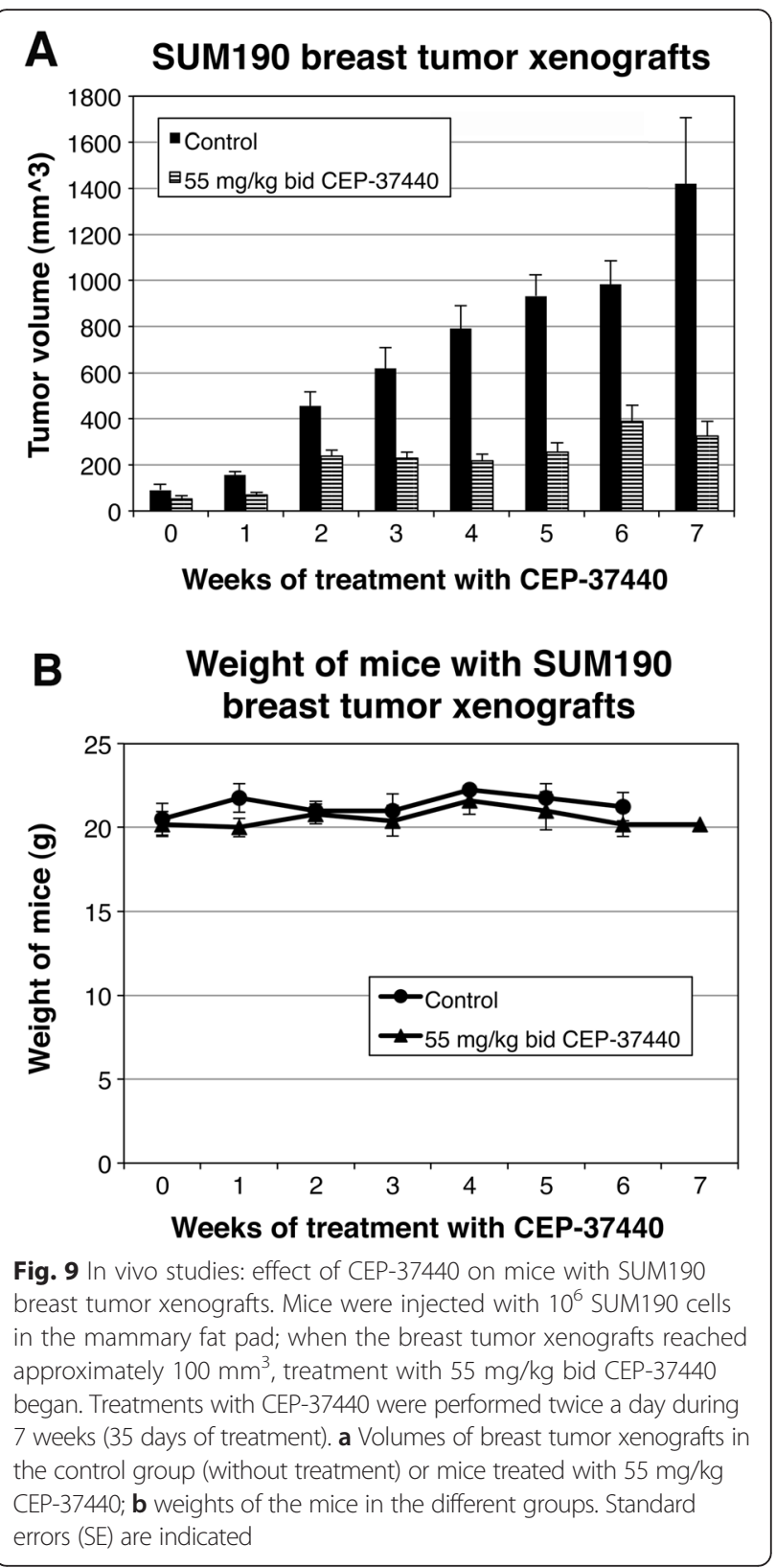

may therefore represent a form of effective "immunemodulatory" therapy that reduces regulatory $\mathrm{T}$ cells in the tumor environment [32]. We showed that CEP37440 treatment of the IBC cell line FC-IBC02 increased the expression of multiple genes related to interferon signaling and cytokines.

In a recent study, FAK1 expression was analyzed in breast primary tumor samples from stages III-IV patients and a significant association between high FAK1 expression in the primary tumor, lymphovascular invasion, and triple-negative phenotype was found. In addition, a strong positive correlation was observed between high FAK1 expression and shorter overall 
survival and progression-free survival in patients with metastatic tumors [33]; however, it was not specified by the authors if IBC samples were included in the study. The role of ALK in IBC is controversial, with some studies showing amplification of ALK in IBC and in others showing no amplification [34,35], and the present work showed that none of the IBC cell lines expressed the ALK protein.

FAK1 is one of the most attractive tyrosine kinase targets in cancer therapy since it plays a role in signal transduction and in the development of numerous human tumors, including breast, colon, thyroid, prostate, pancreas, and brain cancers [36]. Besides CEP-37440, several other small molecule inhibitors of FAK1 that target the ATP-binding site and block FAK1 kinase activity have been developed. One of these inhibitors, PF-562,271 from Pfizer decreased tumor growth in multiple xenograft models $[37,38]$, and was shown to be effective in phase I trials [39]; however, it showed nonlinear pharmacokinetics and was henceforth discontinued. VS-6063 (defactinib) from Verastem showed more favorable pharmacokinetics, and in a phase I trial it demonstrated a favorable response in some patients with ovarian, colorectal, or bile duct cancer. Other FAK1 inhibitors, including VS-4718 (or PND-1186) [40], VS-5095, and GSK2256098, are in early clinical trials.

Finally, our in vivo experiments demonstrated that animals treated with CEP-37440 did not experience reduced body weight or hair loss, suggesting that CEP37440 was not toxic for mice at a dose of 30 or $55 \mathrm{mg} / \mathrm{kg} / \mathrm{bid}$. CEP-37440 is currently in a phase I dose-escalation clinical trial in patients with solid tumors (www.clinicaltrials.gov NCT01922752). Based upon the preclinical studies described above and the data available for other FAK1 inhibitors, CEP-37440 may have clinical applications as part of a combinatorial therapy against IBC.

\section{Conclusions}

These results suggest that CEP-37440 could be effective against IBC cells that express phospho-FAK1 (Tyr 397) if the drug is able to decrease the level of phospho-FAK (Tyr-397). Our results also suggest that combinational therapies could be more effective than using CEP-37440 as a single agent.

\section{Additional files}

Additional file 1: Figure S1. FC-1BC02 cell proliferation assays: estimated time trends in response to different CEP-37440 concentrations in the triple-negative IBC cell line FC-IBC02. (DOC $54 \mathrm{~kb}$ )

Additional file 2: Table S1. FC-IBC02 cell proliferation assays: comparisons from the LME model and time trend estimates by CEP-37440 doses. (DOC $81 \mathrm{~kb})$
Additional file 3: Figure S2. KPL4 cell proliferation assays: estimated time trends in response to CEP-37440 concentrations in the ErbB2-positive IBC cell line KPL4. (DOC 76 kb)

Additional file 4: Table S2. KPL4 cell proliferation assays: comparisons from the LME model for log-transformed responses and time trend estimates. (DOC $56 \mathrm{~kb})$

Additional file 5: Figure S3. SUM190 cell proliferation assays: estimated time trends in response to CEP-37440 concentration in the ErbB2-positive IBC cell line SUM190. (DOC $55 \mathrm{~kb}$ )

Additional file 6: Table S3. SUM190 cell proliferation assays: comparisons from the LME model for log-transformed responses and time trend estimates. (DOC $83 \mathrm{~kb}$ )

Additional file 7: Figure S4. In vivo studies using FC-IBC02 xenograft model: log-transformed tumor volumes and estimated time trends in each group from the LME model. (DOC $44 \mathrm{~kb}$ )

Additional file 8: Table S4. In vivo studies using FC-IBC02 xenograft model: results from the LME model and CEP-37440 treatment comparisons. (DOC $50 \mathrm{~kb}$ )

Additional file 9: Figure S5. In vivo studies using SUM149 xenograft model: log-transformed tumor volumes and estimated time trends in each group from the LME model. (DOC $393 \mathrm{~kb}$ )

Additional file 10: Table S5. In vivo studies using SUM149 xenograft model: results from the LME model and CEP-37440 treatment comparisons. (DOC $56 \mathrm{~kb}$ )

Additional file 11: Table S6. In vivo studies using SUM190 xenograft models. (DOC $39 \mathrm{~kb}$ )

Additional file 12: Supplementary Materials and Methods. Detail description of materials and methods. (DOCX $17 \mathrm{~kb}$ )

\section{Abbreviations}

ALK: anaplastic lymphoma kinase; bid: twice a day; DMSO: dimethyl sulfoxide; EGFR: epidermal growth factor receptor; ELISA: enzyme-linked immunosorbent assay; ErbB2 or HER2: human epidermal growth factor receptor 2; ESR: estrogen receptor; FAK1 (PTK2 or FAK): focal adhesion kinase; $\mathrm{Gl}_{50}$ : drug concentration required to reduce growth rates to $50 \%$; H\&E: hematoxylin and eosin; IBC: inflammatory breast cancer; IPA: Ingenuity Pathway Analysis; LME: linear mixed effects; MTS: 3-(4,5dimethylthiazol-2-yl)-5-(3-carboxymethoxyphenyl)-2-(4-sulfophenyl)-2Htetrazolium salt; NPM: nucleophosmin; PBS: phosphate-buffered saline; PgR: progesterone receptor; PI3K: phosphatidylinositol 3-kinase; PMSF: phenylmethanesulfonyl fluoride; SCID: severe combined immunedeficient; SE: standard error of the mean; StDEV: standard deviation; TGl: tumor growth inhibition; TNBC: triple-negative breast cancer; Treg: T regulatory cells; VEGFR: vascular epidermal growth factor receptor.

\section{Competing interests}

SVF received funds from Teva Pharmaceuticals to perform part of these studies. GRO and BAR were employees of Teva Pharmaceuticals. All remaining authors have declared no competing interests.

\section{Authors' contributions}

IS, MA, and LDA carried out the in vitro assays and animal studies. IC performed statistical analysis of the data and helped in the interpretation of the results. SA performed the microarrays and analysis of microarray data. GRO and BAR participated in the design of the study and interpretation of the results. MC participated in the design and interpretation of the results. SVF coordinated the study, contributed to acquisition of data and interpretation of the results. The manuscript was written by BAR and SVF. All the authors were involved in revising the manuscript critically for important intellectual content. All authors have read and approved the final manuscript.

\section{Acknowledgments}

We thank Dr. Steven McMahon for kindly providing the Karpas 299 cells, and Maria F. Arisi and Jennifer Wilson for language editing of the manuscript. We thank Dr. Thelma Angeles from Teva Pharmaceuticals for performing the $\mathrm{Gl}_{50}$ calculations. 


\section{Grant support}

Israa Salem has been supported with a fellowship from the Saudi Arabian Cultural Mission. This work was supported by PA Breast Cancer Coalition (Refunds for Research Grant to SVF) and Teva Pharmaceuticals (PI: SVF).

\section{Author details}

'Department of Medical Oncology, Thomas Jefferson University, Philadelphia, PA, USA. ${ }^{2}$ Division of Biostatistics, Department of Pharmacology and Experimental Therapeutics, Thomas Jefferson University, Philadelphia, PA, USA. ${ }^{3}$ Cancer Genomics Facility, Kimmel Cancer Center, Thomas Jefferson University, Philadelphia, PA, USA. ${ }^{4}$ Teva Branded Pharmaceutical Products R\&D, West Chester, PA, USA. ${ }^{5}$ Present address: Department of Medicine Hematology and Oncology, Robert H. Curie, Comprehensive Cancer Center, Northwestern University, Chicago, IL, USA. ${ }^{6}$ Present address: Incyte Pharmaceuticals, Wilmington, DE, USA.

\section{Received: 23 October 2015 Accepted: 3 March 2016 Published online: 24 March 2016}

\section{References}

1. Robertson FM, Bondy M, Yang W, Yamauchi H, Wiggins S, Kamrudin S, et al. Inflammatory breast cancer: the disease, the biology, the treatment. CA Cancer J Clin. 2010;60(6):351-75.

2. Cristofanilli M, Valero V, Buzdar AU, Kau SW, Broglio KR, Gonzalez-Angulo AM, et al. Focal breast cancer (IBC) and patterns of recurrence: understanding the biology of a unique disease. Cancer. 2007;110(7):1436-44.

3. Alpaugh ML, Tomlinson JS, Kasraeian S, Barsky SH. Cooperative role of E-cadherin and sialyl-Lewis X/A-deficient MUC1 in the passive dissemination of tumor emboli in inflammatory breast carcinoma. Oncogene. 2002;21(22):3631-43.

4. Molckovsky A, Fitzgerald B, Freedman O, Heisey R, Clemons M. Approach to inflammatory breast cancer. Can Fam Physician. 2009;55(1):25-31.

5. Cristofanilli M, Buzdar AU, Hortobagyi GN. Update on the management of inflammatory breast cancer. Oncologist. 2003;8(2):141-8.

6. Dawood S, Cristofanilli M. Inflammatory breast cancer: what progress have we made? Oncology (Williston Park). 2011;25(3):264-70. 273.

7. Hance KW, Anderson WF, Devesa SS, Young HA, Levine PH. Trends in inflammatory breast carcinoma incidence and survival: the surveillance, epidemiology, and end results program at the National Cancer Institute. J Natl Cancer Inst. 2005;97(13):966-75.

8. Anderson WF, Schairer C, Chen BE, Hance KW, Levine PH. Epidemiology of inflammatory breast cancer (IBC). Breast Dis. 2005;22:9-23.

9. Levine $\mathrm{PH}$, Veneroso $\mathrm{C}$. The epidemiology of inflammatory breast cancer Semin Oncol. 2008;35(1):11-6.

10. Fernandez SV, Robertson FM, Pei J, Aburto-Chumpitaz L, Mu Z, Chu K, et al. Inflammatory breast cancer (IBC): clues for targeted therapies. Breast Cancer Res Treat. 2013;140(1):23-33.

11. Golubovskaya VM, Cance WG. Focal adhesion kinase and p53 signaling in cancer cells. Int Rev Cytol. 2007;263:103-53.

12. Cance WG, Harris JE, lacocca MV, Roche E, Yang $X$, Chang J, et al. Immunohistochemical analyses of focal adhesion kinase expression in benign and malignant human breast and colon tissues: correlation with preinvasive and invasive phenotypes. Clin Cancer Res. 2000;6(6):2417-23.

13. Gabarra-Niecko V, Schaller MD, Dunty JM. FAK regulates biological processes important for the pathogenesis of cancer. Cancer Metastasis Rev. 2003;22(4):359-74

14. McLean GW, Carragher NO, Avizienyte E, Evans J, Brunton VG, Frame MC. The role of focal-adhesion kinase in cancer - a new therapeutic opportunity. Nat Rev Cancer. 2005:5(7):505-15.

15. Sieg DJ, Hauck CR, Ilic D, Klingbeil CK, Schaefer E, Damsky CH, et al. FAK integrates growth-factor and integrin signals to promote cell migration. Nat Cell Biol. 2000;2(5):249-56.

16. Imaizumi M, Nishimura M, Takeuchi S, Murase M, Hamaguchi M. Role of tyrosine specific phosphorylation of cellular proteins, especially EGF receptor and p125FAK in human lung cancer cells. Lung Cancer. 1997;17(1):69-84

17. Itoh S, Maeda T, Shimada M, Aishima S, Shirabe K, Tanaka S, et al. Role of expression of focal adhesion kinase in progression of hepatocellular carcinoma. Clin Cancer Res. 2004;10(8):2812-7.

18. Miyazaki $T$, Kato $H$, Nakajima M, Sohda M, Fukai $Y$, Masuda $N$, et al. FAK overexpression is correlated with tumour invasiveness and lymph node metastasis in oesophageal squamous cell carcinoma. Br J Cancer. 2003:89(1):140-5.

19. Sood AK, Armaiz-Pena GN, Halder J, Nick AM, Stone RL, Hu W, et al. Adrenergic modulation of focal adhesion kinase protects human ovarian cancer cells from anoikis. J Clin Invest. 2010;120(5):1515-23.

20. Rodrigo JP, Dominguez F, Suarez V, Canel M, Secades P, Chiara MD. Focal adhesion kinase and E-cadherin as markers for nodal metastasis in laryngeal cancer. Arch Otolaryngol Head Neck Surg. 2007;133(2):145-50.

21. Jacobs MJ, Ott GR, Courvoisier V. Fused bicyclic 2,4diaminopyrimidinederivative as a dual alk and fak inhibitor. Patent: WO 2013134353 A1, Sep 12, 2013.

22. Horowitz JC, Rogers DS, Sharma V, Vittal R, White ES, Cui Z, et al. Combinatorial activation of FAK and AKT by transforming growth factor-beta1 confers an anoikis-resistant phenotype to myofibroblasts. Cell Signal. 2007:19(4):761-71.

23. Canel M, Secades P, Rodrigo JP, Cabanillas R, Herrero A, Suarez C, et al. Overexpression of focal adhesion kinase in head and neck squamous cell carcinoma is independent of fak gene copy number. Clin Cancer Res. 2006:12(11 Pt 1):3272-9.

24. Liu TJ, LaFortune T, Honda T, Ohmori O, Hatakeyama S, Meyer T, et al. Inhibition of both focal adhesion kinase and insulin-like growth factor-I receptor kinase suppresses glioma proliferation in vitro and in vivo. $\mathrm{Mol}$ Cancer Ther. 2007:6(4):1357-67.

25. Abdel-Ghany M, Cheng HC, Elble RC, Pauli BU. Focal adhesion kinase activated by beta(4) integrin ligation to MCLCA1 mediates early metastatic growth. J Biol Chem. 2002;277(37):34391-400

26. Eke I, Deuse Y, Hehlgans S, Gurtner K, Krause M, Baumann M, et al. beta(1)Integrin/FAK/cortactin signaling is essential for human head and neck cancer resistance to radiotherapy. J Clin Invest. 2012:122(4):1529-40.

27. Shibue T, Weinberg RA. Integrin beta1-focal adhesion kinase signaling directs the proliferation of metastatic cancer cells disseminated in the lungs. Proc Natl Acad Sci U S A. 2009;106(25):10290-5.

28. Kallergi G, Mavroudis D, Georgoulias V, Stournaras C. Phosphorylation of FAK, PI-3 K, and impaired actin organization in CK-positive micrometastatic breast cancer cells. Mol Med. 2007;13(1-2):79-88.

29. Hanks SK, Ryzhova L, Shin NY, Brabek J. Focal adhesion kinase signaling activities and their implications in the control of cell survival and motility. Front Biosci. 2003:8:d982-96

30. Schaller MD, Hildebrand JD, Shannon JD, Fox JW, Vines RR, Parsons JT. Autophosphorylation of the focal adhesion kinase, pp125FAK, directs SH2dependent binding of pp60src. Mol Cell Biol. 1994;14(3):1680-8.

31. Hay N. The Akt-mTOR tango and its relevance to cancer. Cancer Cell. 2005;8(3):179-83.

32. Serrels A, Lund T, Serrels B, Byron A, McPherson RC, von Kriegsheim A, et al. Nuclear FAK controls chemokine transcription, Tregs, and evasion of antitumor immunity. Cell. 2015:163(1):160-73.

33. Golubovskaya VM, Ylagan L, Miller A, Hughes M, Wilson J, Wang D, et al. High focal adhesion kinase expression in breast carcinoma is associated with lymphovascular invasion and triple-negative phenotype. BMC Cancer. 2014;14:769.

34. Kim MH, Lee $\mathrm{S}$, Koo JS, Jung $\mathrm{KH}$, Park IH, Jeong J, et al. Anaplastic lymphoma kinase gene copy number gain in inflammatory breast cancer (IBC): prevalence, clinicopathologic features and prognostic implication. PLoS One. 2015;10(3):e0120320.

35. Krishnamurthy S, Woodward W, Yang W, Reuben JM, Tepperberg J, Ogura D, et al. Status of the anaplastic lymphoma kinase (ALK) gene in inflammatory breast carcinoma. SpringerPlus. 2013;2:409.

36. Ma WW. Development of focal adhesion kinase inhibitors in cancer therapy. Anticancer Agents Med Chem. 2011;11(7):638-42.

37. Roberts WG, Ung E, Whalen P, Cooper B, Hulford C, Autry C, et al. Antitumor activity and pharmacology of a selective focal adhesion kinase inhibitor, PF-562,271. Cancer Res. 2008;68(6):1935-44.

38. Schultze A, Fiedler W. Therapeutic potential and limitations of new FAK inhibitors in the treatment of cancer. Expert Opin Investig Drugs. 2010;19(6):777-88

39. Infante JR, Camidge DR, Mileshkin LR, Chen EX, Hicks RJ, Rischin D, et al. Safety, pharmacokinetic, and pharmacodynamic phase I dose-escalation trial of PF-00562271, an inhibitor of focal adhesion kinase, in advanced solid tumors. J Clin Oncol. 2012;30(13):1527-33.

40. Walsh C, Tanjoni I, Uryu S, Tomar A, Nam JO, Luo H, et al. Oral delivery of PND-1186 FAK inhibitor decreases tumor growth and spontaneous 
breast to lung metastasis in pre-clinical models. Cancer Biol Ther. 2010;9(10):778-90.

41. Kurebayashi J, Otsuki T, Tang CK, Kurosumi M, Yamamoto S, Tanaka K, et al. Isolation and characterization of a new human breast cancer cell line, KPL-4, expressing the Erb B family receptors and interleukin-6. Br J Cancer. 1999;79(5-6):707-17.

42. Ethier SP, Mahacek ML, Gullick WJ, Frank TS, Weber BL. Differential isolation of normal luminal mammary epithelial cells and breast cancer cells from primary and metastatic sites using selective media. Cancer Res. 1993;53(3):627-35.

43. Klopp AH, Lacerda L, Gupta A, Debeb BG, Solley T, Li L, et al. Mesenchymal stem cells promote mammosphere formation and decrease E-cadherin in normal and malignant breast cells. PLoS One. 2010;5(8):e12180.

44. Paine TM, Soule HD, Pauley RJ, Dawson PJ. Characterization of epithelial phenotypes in mortal and immortal human breast cells. Int J Cancer. 1992;50(3):463-73.

45. Soule HD, McGrath CM. A simplified method for passage and long-term growth of human mammary epithelial cells. In Vitro Cell Dev Biol. 1986;22(1):6-12.

46. Cailleau R, Young R, Olive M, Reeves Jr WJ. Breast tumor cell lines from pleural effusions. J Natl Cancer Inst. 1974;53(3):661-74.

Submit your next manuscript to BioMed Central and we will help you at every step:

- We accept pre-submission inquiries

- Our selector tool helps you to find the most relevant journal

- We provide round the clock customer support

- Convenient online submission

- Thorough peer review

- Inclusion in PubMed and all major indexing services

- Maximum visibility for your research

Submit your manuscript at www.biomedcentral.com/submit
Biomed Central 